\title{
New and old challenges in total synthesis. From concept to practice*
}

\author{
Stephen Hanessian ${ }^{\ddagger}$, Roberto Margarita, Adrian Hall, \\ Shawn Johnstone, Martin Tremblay, and Luca Parlanti \\ Department of Chemistry, Université de Montréal, P.O. Box 6128,
Station Centre-ville, Montréal, P.Q., H3C 3J Canada
}

Abstract: The total synthesis of dysinosin A, a novel member of the aeruginosin group of marine natural products is discussed. The stereocontrolled synthesis also confirms the proposed structure and absolute stereochemistry of the natural product.

\section{INTRODUCTION}

One of the historically significant events during the early days of organic synthesis was the total synthesis of (+)-glucose by Emil Fischer in 1890 [1]. The creation of five stereocenters on a six-carbon framework with infinitely limited analytical tools stands as one of the major achievements in stereocontrolled synthesis. One hundred twelve years later, we can reflect upon the multitude of total syntheses of natural products reported and ponder on the state of the art in our cherished subdiscipline [2]—how far we have come since the syntheses of urea, acetic acid, and glucose in the 1890s, and camphor, haemin, and equilenin in the early 1900s.

Consider also the 64 stereogenic centers on a 129-carbon framework of palytoxin, consisting of an acyclic backbone interlaced with five "glucose-like" units. The synthesis of palytoxin was achieved by Kishi and coworkers [3] 100 years after Fischer's (+)-glucose, bringing us full circle from nature's first synthetic man-made enantiopure compound, to one of its largest.

The powerful methodology and sophisticated instrumentation available today have profoundly affected the way in which organic molecules are synthesized and characterized. In spite of the great advances that have enormously facilitated our day-to-day operations, the synthesis of organic molecules even of medium levels of complexity still presents practical, theoretical, and logistical challenges. If time and efficiency are considered as added prime factors, as, for example, in an industrial process, then these challenges are heightened even more. A total synthesis of a life-saving drug that requires more than 20 or 25 steps may be considered to be economically impractical for most pharmaceutical companies.

I have previously reflected upon the art and science of total synthesis [4]. Organic synthesis is a labor-intensive enterprise, that, in spite of its many redeeming features, not the least of which is coworker training, also has its hurdles and challenges. How often have we encountered protective group problems in the penultimate step of a synthesis? Why would the simple oxidation of a primary alcohol suddenly become more recalcitrant to the common methods in an advanced (and precious) intermediate? And what about reaching the final assembly stage of a target molecule after having laboriously synthesized component subunits, only to encounter resistance in their union? Finally, what can we say

\footnotetext{
*Pure Appl. Chem. 75, 141-419 (2003). An issue of reviews and research papers based on lectures presented at the $23^{\text {rd }}$ IUPAC International Symposium on the Chemistry of Natural Products, Florence, Italy, 28 July-2 August 2002 on the theme of natural products.

${ }^{\ddagger}$ Corresponding author
} 
about the puzzlement and, eventually, utter frustration when analysis of the precious few milligrams of a final synthetic product does not quite match the expected physical constants of the authentic material?

Successful completion of a total synthesis is a feeling of exhilaration that is shared by many practitioners of the métier. The monumental accomplishments in this area have also raised the bar considerably in terms of expectations and impact. Nowadays, it is unthinkable (although not impossible) to embark on the total synthesis of a natural product with one or two coworkers, unless the target molecule is of a modest level of complexity. Much can be done in exploratory chemistry and segment synthesis, which help advance our methodologies. But the synthesis of a complex, multifunctional natural product needs a round-the-clock team effort in order to be effective (and competitive). There are, however, remarkably successful cases where complex target molecules were synthesized by one coworker only! Much depends on the type of skeletal construct. For example, some compact polycyclic molecules whose structures can be daunting at first sight, can be relatively easy to assemble by cascade or cycloaddition reactions where multiple bonds are formed in one step [5].

Clearly, each molecule presents its many facets and challenges to the synthetic chemist. In the words of Sophocles, "The first taste is with the eyes". What follows in the mind's eye is a fascinating sequence of events that eventually lead to a synthesis blueprint. From that point on, the adventure begins with high hopes and great expectations of ending it with vintage champagne. Dom Perignon, anyone?

\section{AERUGINOSINS}

The blue-green alga Microcystis aeruginosa is the source of a new class of bioactive peptidic secondary metabolites, known as the aeruginosins [6] (Fig. 1). These compounds exhibit inhibitory activity against the serine proteases thrombin and trypsin. The structures of several members have been elucidated by detailed NMR, by degradative studies, and other methods. For example, the structure and<smiles>CC(C)C[C@H](NC(=O)C(O)c1ccc(O)cc1)C(=O)N1C(C(=O)N[C@@H](CO)CCCNC(=N)N)C[C@@H]2CC[C@@H](O)CC21</smiles>

Aeruginosin 298-A, 1<smiles>CC(C)[C@H](O)[C@H](NC(=O)[C@@H](Cc1ccccc1)[13C](=O)O)C(=O)N1C(C(=O)NCCCCNC(=N)N)C[C@@H]2CC[C@@H](Cl)C[C@H]21</smiles>

Aeruginosin 205-A, 4<smiles>[R]c1cc(C[C@@H](O)C(=O)N[C@@H](C(=O)N2C(C(=O)NCCCCNC(=N)N)C[C@@H]3CC[C@H](OS(=O)(=O)O)C[C@@H]32)C(C)CC)ccc1O</smiles>

Aeruginosin 98-A, $\mathrm{R}=\mathrm{Cl}, 2$ Aeruginosin $98-\mathrm{B}, \mathrm{R}=\mathrm{H}, 3$<smiles>CC(C)CCOc1ccc(C[C@H](O)C(=O)NC(Cc2ccccc2)C(=O)N2C(C(=O)NCCCCNC(=N)N)C[C@@H]3CC[C@@H](O)C[C@H]32)cc1</smiles>

Fig. 1 Structures of selected aeruginosins. 
absolute configuration of aeruginosin 298-A 1 was determined by X-ray crystal analysis as a ternary complex bound to hirugen-thrombin at a resolution of $2.1 \AA$ [7]. The structure of aeruginosin $98-\mathrm{B} 3$ was elucidated as a complex bound to trypsin also by X-ray crystallography [8]. In some cases, the products were isolated as $O$-glycosylated glycopeptides as in aeruginosin 205-A 4 [9] and suomolide [10].

In general, the aeruginosins are characterized by the presence of an octahydroindole carboxylic acid subunit, which is attached to other amine and carboxylic acid residues by peptidic linkages. The ensemble of the peripheral groups provides some of the requisite pharmacophoric sites for binding to the appropriate enzyme. Hitherto known members of this class of marine peptides have a hydroxy or chlorine substituent on the octahydroindole subunit (Fig. 1). A basic terminal functionality acts as an arginine mimetic, while the nature of the other amide residue, which can also carry an acidic sulfate or phenol group, can vary. The single amino acids attached to the octahydroindole amine have a D-configuration, except for L-Phe in microcin SF-608 5 [11] (Fig. 1). The L-Leu originally thought to be present in aeruginosin 298-A [7] was later found to be D-Leu (see below). The aeruginosins are believed to bind to thrombin in a similar manner to D-Phe-Pro-Arg chloromethyl ketone, with the hydrophobic Leu or Phe group occupying the $S_{3}$ subsite, the octahydroindole backbone interacting at the $S_{2}$ subsite, and the guanidine terminus mimicking the arginine at the $S_{3}$ subsite.

Recently, two syntheses of aeruginosin 298-A were published independently by Bonjoch [12] and Wipf [13] and their respective coworkers. Having completed their syntheses, these groups discovered a discrepancy in the comparison of the physical data of their final compound with the authentic natural product [7]. In fact, the culprit was a misassigned L-Leu rather than a D-Leu configuration in the natural product. In both syntheses, D-tyrosine was cleverly manipulated to produce the required hydroxy octahydroindole carboxylic acid in enantioenriched form. Thus, total synthesis was instrumental in the reassignment of configuration to the natural product, in spite of the seemingly reassuring X-ray co-crystal structure data.

\section{DYSINOSIN A: A NEW MEMBER OF THE AERUGINOSIN FAMILY}

Quinn and coworkers [14] have reported the isolation and structure elucidation of structurally novel analogs of the aeruginosins. Dysinosin A (6) was isolated from a new genus and species of sponge of the family Dysideidae, found near Lizard Island in North Queensland, Australia (Fig. 2). Dysinosin A is a potent inhibitor of the blood coagulation factor VIIa as well as of the serine protease thrombin. The structure of dysinosin A was determined by detailed ${ }^{1} \mathrm{H}$ and ${ }^{13} \mathrm{C}$ NMR studies, and its absolute configuration was deduced from an X-ray structure of a complex bound to thrombin [14]. Several structural and functional features distinguish dysinosin A amongst the known aeruginosins. It represents the first analog in which the octahydroindole carboxylic acid subunit is dihydroxylated. The $\mathrm{P}_{3}$ unit does not

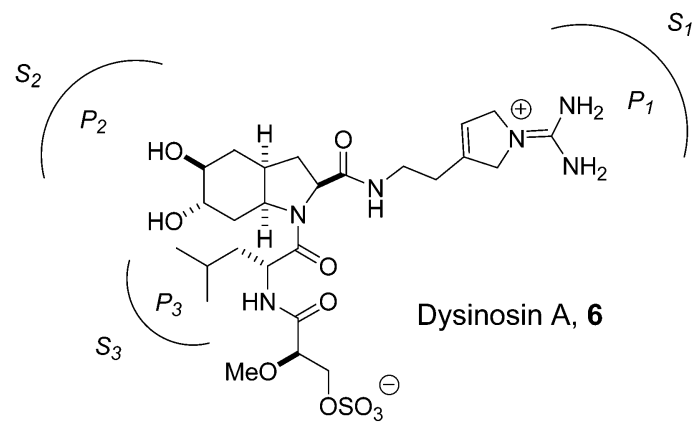

Fig. 2 Structure of dysinosin A. 


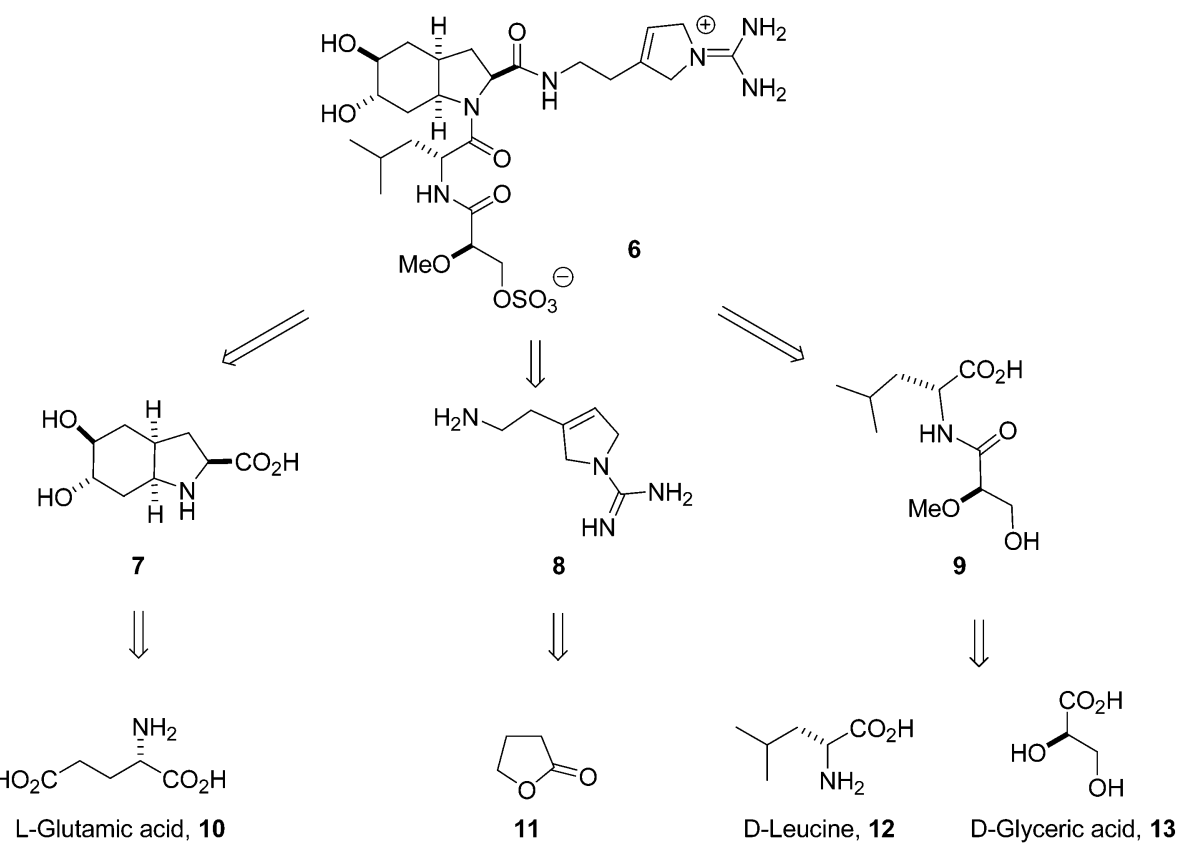

Fig. 3 Disconnection of dysinosin A to subunits and chirons.

have an aromatic moiety, and the $\mathrm{P}_{1}$ unit incorporates the unusual $1-N$-amidino $\Delta-3$ pyrroline, as found in two other aeruginosin-type marine peptides $[10,15]$.

Figure 3 illustrates the disconnection of dysinosin A to three subunits and appropriate chirons. The dihydroxy octahydroindole carboxylic acid $\mathbf{7}$ unit was envisaged to arise from L-glutamic acid as a five-carbon progenitor of the fused bicyclic proline portion. The $O$-sulfated chain can be simply derived from D-leucine and D-glyceric acid, while the four-carbon backbone of the $\Delta$-3-pyrroline was planned to arise from butyrolactone. With this seemingly obvious strategy, we embarked on the total synthesis of dysinosin A, fully aware of the potential pitfalls that may lie ahead.

\section{OCTAHYDROINDOLE CARBOXYLIC ACID}

The challenge in the synthesis of the enantiopure fully functionalized octahydroindole carboxylic acid 7 resided in securing the correct $c i s$-ring junction, and the trans-orientation of the diol unit. To this end, we relied on the prospects of a successful ring-closure metathesis reaction of an all-syn 4,5-di- $C$-allyl L-proline derivative 15 (Fig. 4). Clearly, the main challenge consisted in the elaboration of such a motif, which we chose to construct from the readily available L-glutamic acid as a source of a five-carbon progenitor of the bicyclic proline portion.

We have previously reported [16] that the allylation of a lithium dianion prepared from $\mathrm{N}-\mathrm{Cbz}$ dimethyl L-glutamate $\mathbf{1 6}$ with allyl iodide afforded the corresponding 4-S-allyl analog $\mathbf{1 7}$ as a single product in high yield. Other reactive halides were also investigated to give single isomers of 4-substituted L-glutamates (Scheme 1). These structures were versatile acyclic chirons to afford substituted pyroglutamates or oxo-pipecolates, depending on the selective manipulation of the amino group, the side-chain, or ester groups [16]. The same highly stereoselective $C$-allylation was also possible with the $N$-Boc analog 18, which gave 19 in excellent yield (Scheme 2). The highly stereoselective $C$-allylation of the dianion can be explained by assuming a Li-chelated intermediate (shown as the $E$-enolate for convenience). Previous reports from our laboratory have also shown examples of high stereoselectivity in 
<smiles>C=C=CC(=O)C1C[C@@H]2CC(O)[C@@H](O)C[C@H]2N1</smiles>
7

Fig. 4 L-glutamic acid as precursor.<smiles>[R]OC(=O)C1CC(CC=C)C(CC=C)N1[R6]</smiles><smiles>N[C@@H](CCC(=O)O)C(=O)O</smiles>

10<smiles>CC(=O)CCC(NC(C)=O)C(C)=O</smiles>

16<smiles>CC=CCC(CC(CC=CC)C(C)OC(C)=O)C(C)=O</smiles>

$89 \%$<smiles>CC(=O)N[C@@H](CC(C/C=C/c1ccccc1)C(C)=O)C(C)=O</smiles>

$80 \%$

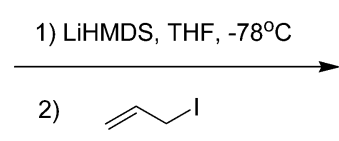

$93 \%$<smiles>C=CCC(C[C@H](NC(C)=O)C(C)=O)C(C)=O</smiles>

17<smiles>C=C(CC(C[C@H](NC(C)=O)C(C)=O)C(=O)OC)OC</smiles>

$65 \%$

Scheme 1<smiles>C=C(C)CC(CC(NC(C)=O)C(C)=O)C(C)=O</smiles>

$82 \%$<smiles>CC(=O)N[C@@H](CC(Cc1ccccc1)C(C)=O)C(C)=O</smiles>

$77 \%$<smiles>CC(=O)N[C@@H](CC(C)C(C)=O)C(C)=O</smiles>

$73 \%$<smiles>COC(=O)CC[C@H](NC(C)=O)C(=O)OC</smiles>

18
1) LiHMDS, THF, $-78^{\circ} \mathrm{C}$

2)<smiles>C=CCC(CC(NC(=O)OCc1ccccc1)C(C)=O)C(C)=O</smiles>

19

$92 \%$

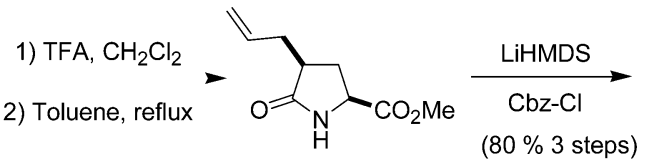

20

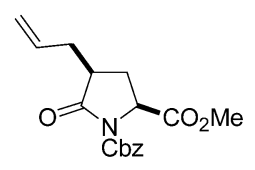

21

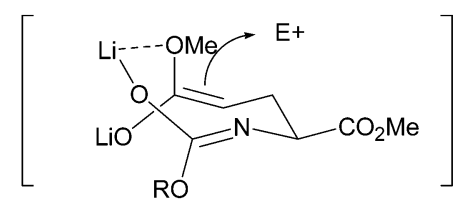

22

\section{Scheme 2}

(C) 2003 IUPAC, Pure and Applied Chemistry 75, 209-221 
related alkylations [17]. We were now in a position to transform 19 into the 4-allylated pyroglutamate 20 and its $\mathrm{N}$-Cbz derivative 21.

The first stereochemical hurdle to overcome was encountered in the attempted introduction of a second $C$-allyl group with the all-syn orientation via $N$-acyl iminium ion chemistry [18]. Reduction of representative $N$-protected pyroglutamates with lithium triethylborohydride followed by acetylation gave the corresponding 5-acetoxy derivatives, which were subjected to $C$-allylation in the presence of various Lewis acids. Table 1 lists variations in the nature of the leaving group, the ester, and the $N$-protective group [19]. Lewis acid-catalyzed allylation with allylsilanes and allylstannanes afforded mixtures with only modest levels of selectivity, often favoring the undesired isomer. After considerable experimentation, it was found that the best ratio (5.5:1) favoring the desired syn-isomer 25 was obtained with allyltributylstannane in the presence of $\mathrm{BF}_{3} \cdot \mathrm{Et}_{2} \mathrm{O}$ in toluene at $-78{ }^{\circ} \mathrm{C}$. Curiously, under the same conditions, but using the $N$-Boc group instead of $N$-Cbz gave a 1:2 ratio of syn/anti isomers (Scheme 3).

Table 1 Addition of allyl nucleophiles to $N$-acyl iminium ions.

\begin{tabular}{|c|c|c|c|c|c|c|}
\hline $\mathrm{P}$ & $\mathrm{R}$ & L.A. & $X$ & Solvent & Yield (\%) & Syn/anti \\
\hline Boc & $\mathrm{Me}$ & $\mathrm{Et}_{2} \mathrm{O} \cdot \mathrm{BF}_{3}$ & $\mathrm{Bu}_{3} \mathrm{Sn}$ & DCM & 73 & $2: 1$ \\
\hline Boc & $\mathrm{Me}$ & $\mathrm{Et}_{2} \mathrm{O} \cdot \mathrm{BF}_{3}$ & TMS & $\mathrm{MeCN}$ & 50 & $1: 3$ \\
\hline Boc & $\mathrm{Me}$ & $\mathrm{Et}_{2} \mathrm{O} \cdot \mathrm{BF}_{3}$ & TMS & $\mathrm{PhMe}$ & $<35$ & $1: 2$ \\
\hline Boc & $\mathrm{Me}$ & $\mathrm{TiCl}_{4}$ & TMS & DCM & 40 & $1: 2.7$ \\
\hline Boc & $\mathrm{Me}$ & TMSOTf & TMS & DCM & 36 & $1: 2$ \\
\hline Boc & $i$-Pr & $\mathrm{Et}_{2} \mathrm{O} \cdot \mathrm{BF}_{3}$ & TMS & DCM & 40 & $1: 1$ \\
\hline $\mathrm{Cbz}$ & $\mathrm{Me}$ & $\mathrm{Et}_{2} \mathrm{O} \cdot \mathrm{BF}_{3}$ & TMS & DCM & 77 & $1.5: 1$ \\
\hline Fmoc & $\mathrm{Me}$ & $\mathrm{Et}_{2} \mathrm{O} \cdot \mathrm{BF}_{3}$ & TMS & DCM & 77 & $3: 1$ \\
\hline TEOC & $\mathrm{Me}$ & $\mathrm{Et}_{2} \mathrm{O} \cdot \mathrm{BF}_{3}$ & TMS & DCM & 25 & $1: 2$ \\
\hline $\mathrm{CO}_{2} \mathrm{Me}$ & $\mathrm{Me}$ & $\mathrm{Et}_{2} \mathrm{O} \cdot \mathrm{BF}_{3}$ & TMS & DCM & 83 & $1.5: 1$ \\
\hline $\mathrm{CO}_{2} \mathrm{Me}$ & $i-\operatorname{Pr}$ & $\mathrm{Et}_{2} \mathrm{O} \cdot \mathrm{BF}_{3}$ & TMS & DCM & 70 & $1.2: 1$ \\
\hline $\mathrm{CO}_{2} \mathrm{Me}$ & $t-\mathrm{Bu}$ & $\mathrm{Et}_{2} \mathrm{O} \cdot \mathrm{BF}_{3}$ & TMS & DCM & 60 & $4: 1$ \\
\hline
\end{tabular}

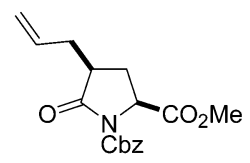

21

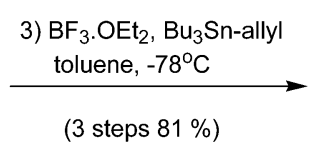

(3 steps $81 \%$ )

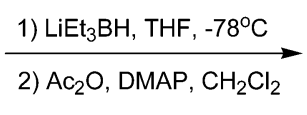

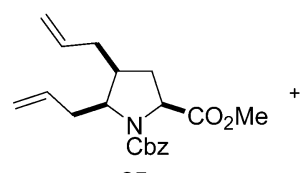

25

syn/anti 5.5:1

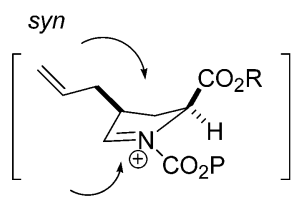

anti 24

(c) 2003 IUPAC, Pure and Applied Chemistry 75, 209-221 
It is difficult to rationalize the influence of the solvent and the $N$-protective group in these alkylations, particularly in view of the apparent dominance of steric factors for the all syn-product $\mathbf{2 5}$. 1,3-Allylic strain is known to exert an influence in reactions of related iminium ions [20]. Depending on the orientation of the ester group, and the preferred conformation of the iminium ion $\mathbf{2 4}$, an internally assisted approach of the allystannane or the Lewis acid by coordination to the ester carbonyl may be postulated.

Having obtained a preparatively useful ratio of the desired precursor $\mathbf{2 5}$, we embarked on the elegant Grubbs ring-closure metathesis [21], which has many precedents for the synthesis of related heterocycles, particularly of the indolizidinone type [22]. Carbocyclization was successfully achieved using the first generation catalyst $\mathbf{2 7}$, which led to the hexahydroindole carboxylic ester derivative $\mathbf{2 8}$ in superb yield [23]. The anti-isomer $\mathbf{2 6}$ was equally well cyclized to give 29. Remarkably, both ring junctions were attained without an apparent preference for one or the other, as reflected in the quasi-identical and excellent yields (Scheme 4). Nuclear Overhauser effects confirmed the assigned structures and stereochemistries.<smiles>C=CCC1CC(C(C)=O)N(C(C)=O)C1CC=C</smiles>

syn-25<smiles>C=CCC1CC(C(C)=O)N(C(C)=O)[C@@H]1CC=C</smiles>

anti-26

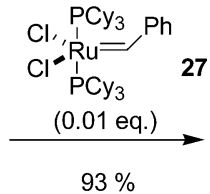

$93 \%$

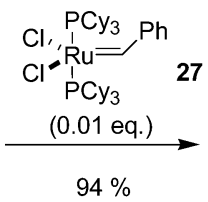

$94 \%$<smiles>CC(=O)OC1C[C@H]2CC=CC[C@H]2N1C(=O)OCc1ccccc1</smiles>

28<smiles>CC(=O)OC(=O)N1C(C(=O)OCc2ccccc2)C[C@@H]2CC=CCC21</smiles>

29

Scheme 4

The next challenge was to functionalize the cyclohexene-type olefin en route to a trans-S,S-diol 31 (Scheme 5). Epoxidation with $m$-CPBA was expected to take place from the more exposed convex $\alpha$-face of the bicyclic system. In the event, treatment with $m$-CPBA gave a single epoxide. After exploring several mild acidic conditions including Dowex-50 $\left(\mathrm{H}^{+}\right)$, it was found that trifluoroacetic acid in aqueous tetrahydrofuran (THF) effected smooth ring-opening to afford the desired trans-diol $\mathbf{3 1}$ in

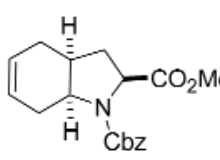

28

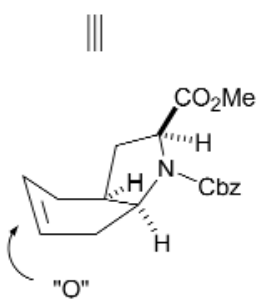

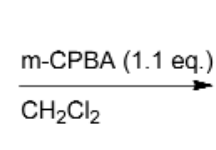

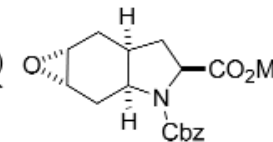

30

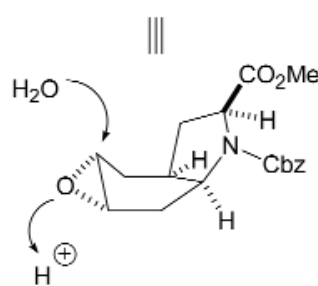

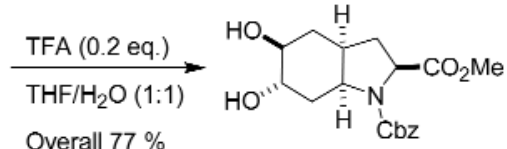

31

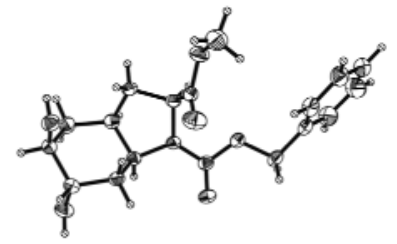

Scheme 5 
excellent overall yield. The absolute stereochemistry of $\mathbf{3 1}$, hence of all its precursors was ascertained from an X-ray crystal structure in which the trans-diaxial orientation of the diol in a chair-like cyclohexane subunit was evident (Scheme 5).

\section{ACYCLIC D-LEUCYL PEPTIDE}

The D-leucyl peptide subunit was synthesized by the most obvious route, taking advantage of the easy access to 3-O-methyl D-glyceric acid from D-mannitol [24] (Scheme 6). Thus, $O$-methylation of the bis- $O$-benzylidene acetal $\mathbf{3 2}$ followed by hydrogenolysis and selective silylation afforded $\mathbf{3 3}$. Oxidative cleavage led to the desired chiron $\mathbf{3 4}$ in excellent overall yield. Amidic coupling with D-leucine benzyl ester, followed by hydrogenolytic cleavage of the ester gave the desired D-leucyl peptide acid $\mathbf{3 5}$.

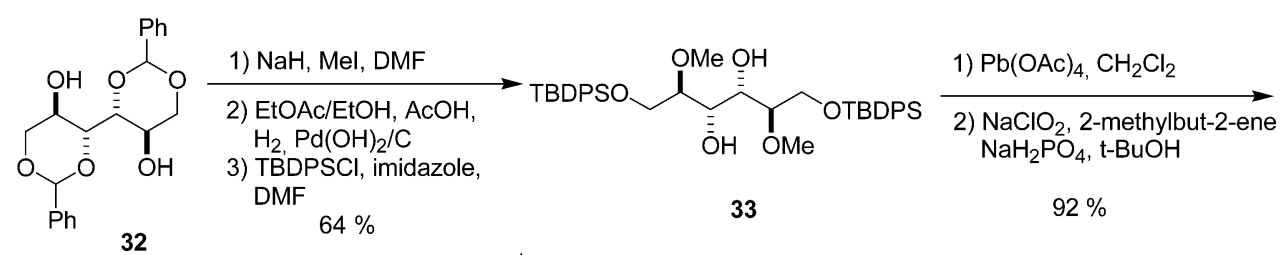

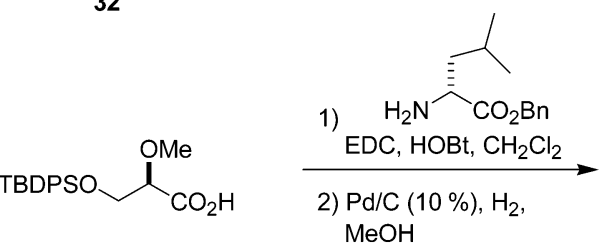

34

$80 \%$<smiles>COC(COS(=O)(=O)OC(C)(C)C)C(=O)NC(CC(C)C)C(=O)O</smiles>

35

Scheme 6

\section{3-PYRROLINE SUBUNIT}

The synthesis of the corresponding $N$-phthalimido, bis- $N$-Boc analog has been reported in the patent literature [15]. The cyclocondensation of methyl $N$-Boc glycinate with ethyl acrylate under basic conditions afforded a 4-keto-3-ethoxycarbonyl $N$-Boc pyrrolidine, which was reduced, then $\beta$-eliminated to afford the corresponding $N$-Boc-3-ethoxycarbonyl 3-pyrroline. Further manipulation led to the target pyrroline. Alternative syntheses of simple 3-pyrrolines are also known [25], including the use of ringclosure metathesis [26].

Our synthesis started with the methyl ester 36, readily available from butyrolactone [27] (Scheme 4). Protection of the primary hydroxyl group, followed by reduction of the ester and introduction of an allylamine group by displacement of an allylic mesylate 38, and $\mathrm{N}$-Boc protection gave the key intermediate 39 in excellent overall yield. Ring-closure metathesis gave the branched 3-pyrroline derivative 40 in $90 \%$ yield. Deprotection of the silyl group followed by Mitsunobu azidation [28] and introduction of the bis- $N$-Boc amidino group [29] afforded 41. Reduction to $\mathbf{4 2}$ via a Staudinger reaction, and acetylation of the resulting amine gave the crystalline $\mathbf{4 3}$, whose structure was definitively established by X-ray analysis (Scheme 7). In another study in which the phthalimido group was present at the extremity of the two-carbon chain instead of the silyl ether in 39, metathesis was also successful, albeit in modest yield, presumably due to the coordination of the catalyst to the heterocycle [30]. 

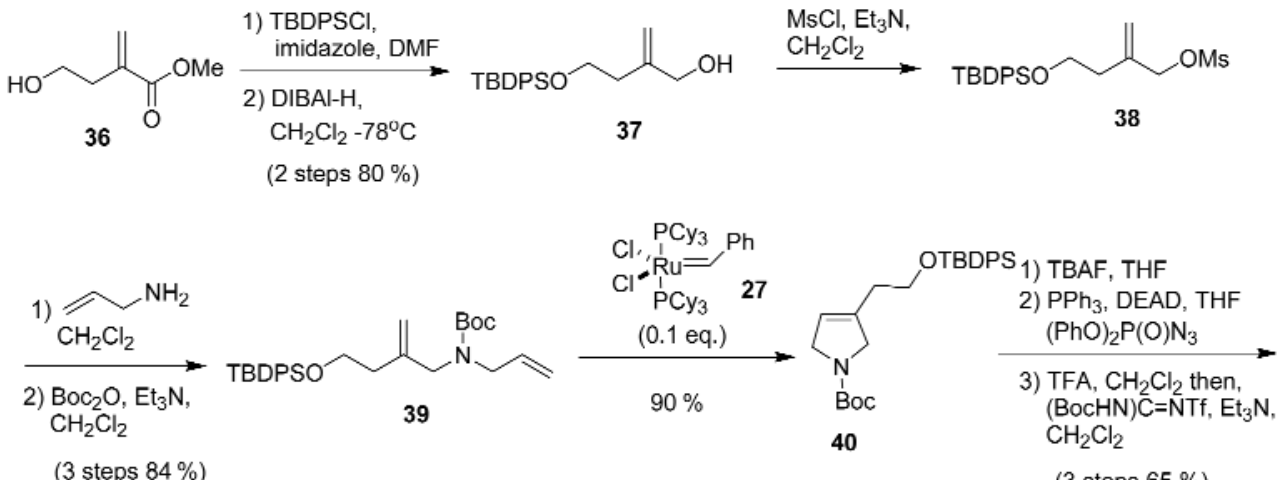

(3 steps $84 \%$ )

(3 steps $65 \%$ )

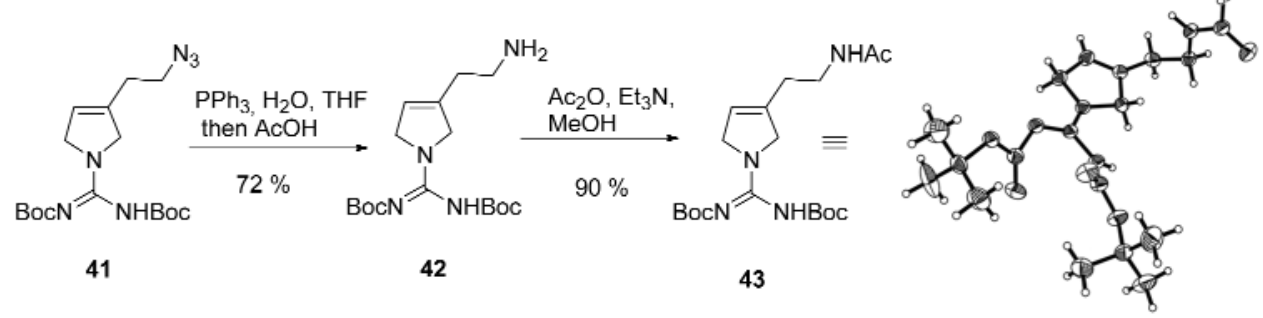

Scheme 7

\section{DYSINOSIN A: THE ASSEMBLY}

With the three subunits in hand (Fig. 3), we were now poised to assemble the target molecule. In preliminary studies, we attempted a direct coupling of the D-leucyl peptide portion $\mathbf{3 5}$ with the free octahydroindole carboxylic acid methyl ester $\mathbf{3 1}$ (after removal of the $\mathrm{N}$-Cbz group). Although peptide coupling took place, the yields were modest and we observed competing $O$-esterification as well. Protection of the diol as acetates afforded mixtures of mono and diacetates, in addition to some $O$ - to $\mathrm{N}$-acetyl migration as a competing reaction to peptidic coupling. We therefore decided to continue with a more secure route, at the expense of adding two extra steps to the synthesis (Scheme 8). Thus, transformation of $\mathbf{3 1}$ to the corresponding bis-MOM ether and cleavage of the Cbz group by hydrogenolysis afforded 44. Coupling with $\mathbf{3 5}$ under standard conditions gave the desired adduct, which upon treatment with $\mathrm{LiOH}$ in aqueous THF gave the free carboxylic acid derivative $\mathbf{4 5}$.

Amide formation between $\mathbf{4 2}$ and $\mathbf{4 5}$ proceeded smoothly to afford the quasi-penultimate intermediate 46 (Scheme 9). Removal of the silyl protective group gave the primary alcohol, which was subjected to several conditions of $O$-sulfation. The most efficient method proved to be the one that activates the alcohol [31] by treatment with a catalytic quantity of dibutyltin oxide, followed by sulfation with pyridine $\cdot \mathrm{SO}_{3}$ complex [32]. Subsequent treatment with aqueous trifluoroacetic acid cleaved the $N$-Boc and $O$-MOM groups affording dysinosin A, which, after being purified by preparative reverse-phase high-performance liquid chromatography (HPLC), was found to be identical to the natural product in all respects (HPLC, ${ }^{1} \mathrm{H},{ }^{13} \mathrm{C}$ NMR, FAB, and electrospray mass spectrometry). 


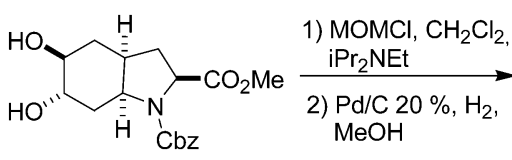

31

$93 \%$<smiles>COC(=O)[C@H]1C[C@@H]2C[C@H](OC)[C@H](OC)C[C@@H]2N1</smiles>

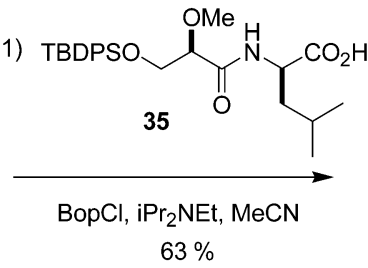

2) $\mathrm{LiOH}, \mathrm{THF}, \mathrm{MeOH}$
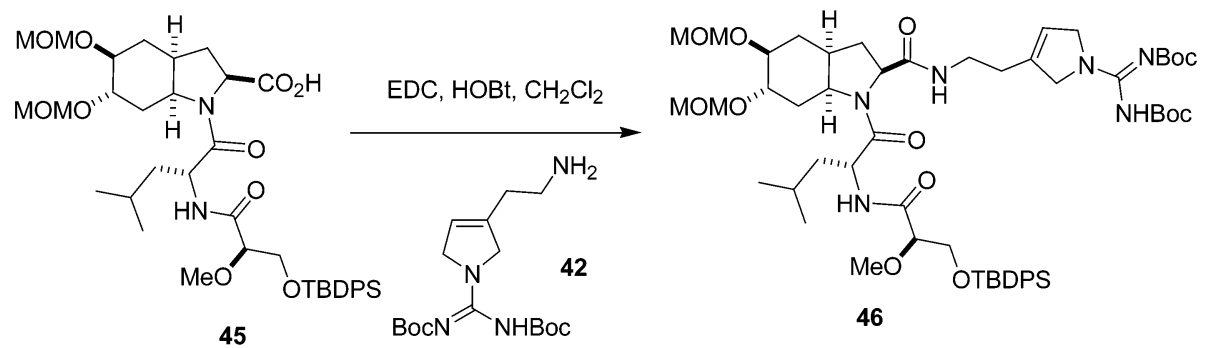

(2 steps $92 \%)$

Scheme 8
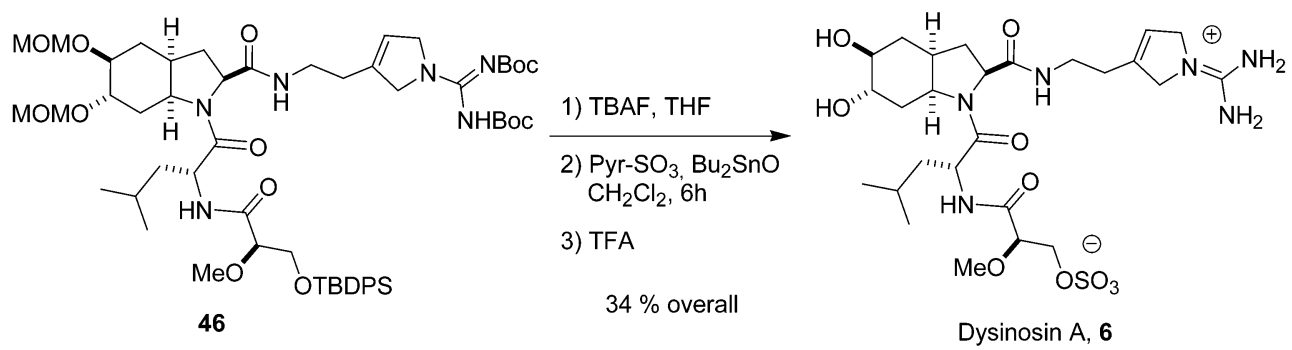

Scheme 9

\section{SYNOPSIS}

The total synthesis of dysinosin A was achieved by a highly stereocontrolled route using in part the chiron approach. Although the structure of dysinosin A was elegantly deduced from NMR studies and from the co-crystal data as a thrombin complex by Quinn and coworkers [14], securing an independent proof by total synthesis provided definitive confirmation of the proposed absolute configuration. In spite of its enormous utility in structure elucidation and in inhibitor design [33], X-ray co-crystal structure determination can, in isolated instances, be subject to revision [7]. The utility of total synthesis for structural and configurational identity with a proposed molecule, and the opportunity to develop or apply new and old methodologies remain as strong incentives in target-oriented synthesis. In this regard, it is of interest to recapitulate the disconnections and the simplification of the dysinosin A structure to its precursor subunits. Acyclic stereoselection was successfully applied to functionalize L-glutamic acid via a 1,3-induction, and the product was further manipulated to afford an all syn-trisubstituted L-proline intermediate. The versatile Grubbs metathesis reaction was then used to generate a hexahydroindole carboxylic acid subunit. Highly stereocontrolled epoxidation and dihydroxylation reactions completed the synthesis of the bicyclic core motif. Butyrolactone was the source of the four-carbon atoms in the $\Delta$-3-pyrroline, and allylamine was the source of the nitrogen atom. A second Grubbs metathesis of a bis-allylic amine derivative led to the desired branched $\Delta$-3-pyrroline. 
The ensemble of these transformations gave us an opportunity to test "new" methodologies, (e.g., olefin metathesis), and to apply "old" reactions (e.g., iminium ion and enolate chemistry) to eventually achieve the synthetic objective. After the fact, we can ask ourselves: Have we invented any new reactions or uncovered novel concepts in reaching this mini-summit that was dysinosin $\mathrm{A}$ ? The answer would be no. Have we learned lessons in functional group compatibility, selective manipulation, stereocontrolled bond formation, and target assembly (even by seemingly simple peptide coupling)? The answer here is a definite yes. Along the way, we have also provided good training to a group of talented young coworkers, who have now experienced the wonderful and at times enigmatic world of natural product synthesis [34].

The methodology developed in this first total synthesis of dysinosin A as described in this article should pave the way to other congeners, as well as to the design of analogs with the objective of improving its antithrombotic activity [35].

\section{ACKNOWLEDGMENTS}

We thank NSERC for financial assistance through the Medicinal Chemistry Chair Program. We are grateful to AstraZeneca for their support, particularly Drs. David Rees and Kenneth Granberg. We very much appreciate our collaboration with Dr. Ron Quinn and his group at Griffith University, Brisbane, Australia. X-ray crystal structures of intermediates were determined at the Université de Montréal by Dr. Michel Simard. M.T. acknowledges FCAR and NSERC for scholarships.

\section{REFERENCES}

1. For the contributions of Emil Fischer to carbohydrate chemistry, see K. Freudenberg. Advan. Carbohydr. Chem. 21, 1 (1966).

2. See, for example: (a) K. C. Nicolaou, D. Vourloumis, N. Winssinger, P. S. Baran. Angew. Chem., Int. Ed. 39, 44 (2000); (b) K. C. Nicolaou and E. J. Sorensen. Classics in Total Synthesis, VCH, Weinheim (1996); (c) E. J. Corey and S.-M. Cheng. The Logic of Chemical Synthesis, Wiley, New York (1989).

3. R. W. Armstrong, J.-M. Beau, S. H. Cheou, W. J. Christ, H. Fujioka, W.-H. Ham, L. D. Hawkins, H. Jin, S. H. Kang, Y. Kishi, M. J. Martinelli, W. W. McWhorter, Jr., M. Mizuno, M. Nakata, A. E. Stutz, F. X. Talamas, M. Taniguchi, J. A. Tino, K. Ueda, J. Uenishi, J. B. White, M. Yonaga. J. Am. Chem. Soc. 111, 7525 (1989).

4. (a) S. Hanessian. In Chemical Synthesis, C. Chatigilialoglu and V. Snieckus (Eds.), p. 61 (1996); (b) S. Hanessian. Pure Appl. Chem. 65, 1189 (1993); (c) S. Hanessian. Pure Appl. Chem. 62, 1887 (1990).

5. See, for example: (a) K. Neuschütz, J. Verlker, R. Neier. Synthesis, 227 (1998); (b) L. F. Tietze. Chem. Rev. 96, 115 (1996).

6. (a) A. Ploutno, M. Shoshan, S. Carmeli J. Nat. Prod. 65, 973 (2002); (b) K. Ishida, Y. Okita, H. Matsuda, T. Okino, M. Murakami. Tetrahedron 55, 10971 (1999); (c) S. Kodani, K. Ishida, M. Murakami. J. Nat. Prod. 61, 1046 (1998); (d) H. Matsuda, T. Okino, M. Murakami, K. Yamaguchi. Tetrahedron 52, 14501 (1996); (e) M. Murakami, K. Ishida, T. Okino, Y. Okita, H. Matsuda, K. Yamaguchi. Tetrahedron Lett. 36, 2785 (1995).

7. J. L. R. Steiner, M. Murakami, A. Tulinsky. J. Am. Chem. Soc. 120, 597 (1998).

8. B. Sandler, M. Murakami, J. Clardy. J. Am. Chem. Soc. 120, 595 (1998).

9. H. J. Shin, H. Matsuda, M. Murakami, K. Yamaguchi. J. Org. Chem. 62, 1810 (1997).

10. K. Fujii, K. Sironen, K. Adachi, K. Noguchi, Y. Shimizu, H. Sano, K. Hirayama, M. Suzuki, K. Hirada. Tetrahedron Lett. 38, 5529 (1997).

11. (a) N. Valls, M. Vallribera, M. López-Canet, J. Bonjoch. J. Org. Chem. 67, 4945 (2002); (b) R. Banker and S. Carmeli. Tetrahedron 55, 10835 (1999). 
12. N. Valls, M. López-Canet, M. Vallribera, J. Bonjoch. J. Am. Chem. Soc. 122, 11248 (2000).

13. P. Wipf and J.-L. Methot. Org. Lett. 2, 4213 (2000).

14. A. R. Carroll, G. Pierens, G. Fechner, P. De Almeida Leone, A. Ngo, M. Simpson, J. N. A. Hooper, S.-L. Boström, D. Musil, R. J. Quinn. J. Am. Chem. Soc. In press.

15. R. Engh, S. Konetschny-Rapp, H.-W. Krell, U. Martin, C. Tsklakidis. PCT Pat. No. WO97121725. Chem. Abstr. 127, 12202 (1997).

16. S. Hanessian and R. Margarita. Tetrahedron Lett. 39, 5887 (1999).

17. S. Hanessian and R. Schaum. Tetrahedron Lett. 38, 163 (1997).

18. (a) W. Speckamp and M. J. Moolenaar. Tetrahedron 5, 3817 (2000); (b) H. Hiemstra and N. Speckamp. In Comprehensive Organic Synthesis, B. M. Trost, I. Fleming, C. H. Heathcock (Eds.), Vol. 2, p. 1047 (1991); for selected examples of addition of carbon nucleophililes to $\mathrm{N}$-acyliminium ions, see: (c) I. Collado, J. Ezquerra, C. Pedergal. J. Org. Chem. 60, 5011 (1995); (d) T. Shono, Y. Matsumura, K. Tsubata, K. Uchida. J. Org. Chem. 51, 2590 (1986); (e) K. F. McLure, P. Renold, D. S. Kemp. J. Org. Chem. 60, 454 (1995); (f) P. Renaud and D. Seebach. Helv. Chim. Acta 69, 1704 (1986).

19. See, for example: M. V. Chiesa, L. Manzoni, C. Scolastico. Synlett 441 (1996).

20. See, for example: (a) S. Hanessian, W. A. L. van Otterlo, I. Nilsson, U. Bauer. Tetrahedron Lett. 43, 1995 (2002); (b) J. D. Brown, M. A. Foley, D. L. Comins. J. Am. Chem. Soc. 110, 7445 (1988); (c) M. Sugiura, H. Hagio, R. Hirabayashi, S. Kobayashi. J. Am. Chem. Soc. 123, 12510 (2001).

21. For recent reviews, see: (a) R. Grubbs and S. Chang. Tetrahedron 54, 4413 (1998); (b) S. K. Armstrong. J. Chem. Soc. Perkin Trans. 371 (1988); (c) A. Fürstner, M. Picquet, C. Bruneau, P. H. Dixneuf. Chem. Commun. 1315 (1998); (d) M. Schuster and S. Blechert. Angew. Chem., Int. Ed. Engl. 36, 2036 (1997); (e) R. H. Grubbs, S. J. Miller, C. G. Fu. Acc. Chem. Res. 28, 446 (1995).

22. L. M. Beal and K. D. Moeller. Tetrahedron Lett. 39, 4639 (1998); (b) C. E. Grossmith, F. Senia, J. Wagner. Synlett 1660 (1999); (c) S. H. Lim, S. Ma, P. Beak. J. Org. Chem. 66, 9056 (2001).

23. For the synthesis-related structures, see (a) I. Coldham, K. M. Crapnell, J. D. Mosely, R. Rabot. J. Chem. Soc., Perkin Trans. 11758 (2001); (b) L. Belvisi, L. Colombo, M. Colombo, M. DiGiacomo, L. Manzoni, B. Vodopirec, C. Scolastico. Tetrahedron 57, 6463 (2001); (c) P. Wipf and D. A. Maresko. Tetrahedron Lett. 41, 4723 (2000); (d) P. Wipf and W. Li. J. Org. Chem. 64, 4576 (1999); P. Wipf, Y. Kim, D. M. Goldstein. J. Am. Chem. Soc. 117, 1606 (1995); (f) J. Bonjoch, J. Catena, E. Isabal, M. López-Canet, N. Valls. Tetrahedron: Asymmetry 7, 1899 (1996); (g) L. M. Harwood and I. A. Lilley. Tetrahedron Lett. 34, 537 (1993); (h) L. M. Harwood and L. C. Kitchen. Tetrahedron Lett. 34, 6603 (1993); (i) T. Waga, S. Matsui, S. Saito, M. Watanable, Y. Kaijiwara, M. Shirota, M. Iijima, K. Kitabatake. Drug Res. 40, 407 (1990); (j) R. Henning and H. Rubach. Tetrahedron Lett. 24, 5339 (1983), and references cited therein.

24. K. C. Nicolaou, A. D. Piscopio, P. Bertinato, T. K. Chakraborty, N. Minowa, K. Koide. Chem. Eur. 1, 318 (1995).

25. For the synthesis of $\Delta-3$ pyrrolines, see: X. Wang, J. F. Espinosa, S. H. Gellman. J. Am. Chem. Soc. 122, 4821 (2000); see also refs. 4, 18.

26. For the synthesis of $\Delta-3$ pyrrolines by ring-closure methathesis, see: (a) H. Wakamatsu and S. Blechert. Angew. Chem., Int. Ed. 41, 2403 (2002); (b) A. Briot, M. Bujard, V. Gouverneur, S. P. Nolan, C. Mioskowski. Org. Lett. 2, 1517 (2000); (c) M. Mori, N. Sakakibara, A. Kinoshita. J. Org. Chem. 63, 6082 (1998).

27. R. Grigg, J. Markandu, T. Perrior, S. Surendrakumar, W. J. Warnock. Tetrahedron 48, 6929 (1992).

28. A. S. Thompson, G. R. Humphrey, A. M. De Marco, D. J. Mathre, E. J. J. Grabowski. J. Org. Chem. 58, 5886 (1993). 
29. K. Feichtinger, H. L. Singh, T. J. Baker, K. Mathews, M. Goodman. J. Org. Chem. 63, 8432 (1998).

30. See, for example, (a) G. Fu and R. H. Grubbs. J. Am. Chem. Soc. 114, 7324 (1992); (b) M. Schuster and S. Blechert. Angew. Chem., Int. Ed. Engl. 36, 2043 (1997).

31. S. Hanessian and S. David. Tetrahedron 41, 643 (1985).

32. (a) A. Lubineau and R. Lemoine. Tetrahedron Lett. 35, 8795 (1994); (b) W. J. Sanders, D. D. Manning, K. M. Koeller, L. L. Kiessling. Tetrahedron 53, 16391 (1997); (c) M. Martinelli, R. Vaidyanathan, J. M. Pawlak, N. K. Nayyar, U. P. Dhokte, C. W. Doecke, L. M. Zollars, E. D. Moher, V. V. Khau, B. Kosmrlj. J. Am. Chem. Soc. 124, 3578 (2002).

33. See, for example, (a) A. D. Leung, G. Abbenante, D. P. Fairlie. J. Med. Chem. 43, 305 (2000); (b) H. Kubinyi. Curr. Opin. Drug Disc. Develop. 1, 4 (1998); (c) R. E. Babine and S. L. Bender. Chem. Rev. 97, 1359 (1997).

34. For the total synthesis of dysinosin A, see: S. Hanessian, R. Margarita, A. Hall, S. Johnstone, M. Tremblay, L. Parlanti. J. Am. Chem. Soc. In press.

35. For reviews on thrombin, see: (a) T. Steinmetzer, J. Hauptmann, J. Stürzebecher. Exp. Opin. Invest. Drugs 10, 845 (2000); (b) P. E. J. Sanderson and A. M. Nayler-Olsen. Curr. Med. Chem. 5, 289 (1998); (c) R. W. Colman, V. J. Marder, E. W. Salzman, W. Hirsch. In Hemostasis and Thrombosis; Basic Principles and Clinical Practice, $3^{\text {rd }}$ ed., R. W. Colman, J. Hirsch, V. J. Marder, E. W. Salzman (Eds.), J. B. Lippincott, Philadelphia; (d) M. Kalafatis, J. O. Egan, C. van't Veer, K. Cawthern, K. G. Mann. Curr. Rev. Eukaryotic Gene Expression 7, 241 (1997); (e) B. N. Bouma, P. A. K. von dem Borne, J. C. M. Meijers. Thromb. Haemost. 80, 24 (1998); (f) K. G. Mann. Thromb. Haemost. 82, 165 (1999). 